\title{
Accessible Transportation System for the Disabled Tourist in the National Park of Johor State, Malaysia
}

\author{
Shalini Sanmargaraja and Seow Ta Wee
}

\begin{abstract}
Tourism is a rapidly growing industry in the Asian and Pacific Region, disabled person and older persons are becoming a growing group of consumers of travel, sports and other leisure-oriented products and services. However, their travel experiences are still characterized by transportation constraints, inaccessible accommodation and tourism sites, and inadequate customer services. Purpose of this paper is to identify the constraints gone through by the disabled tourists in the transportation services in the National Parks in Johor State. From the observation and interview session, it is found that there is no public transportation service in the entire park and inadequate of other support facilities which are essential for the disabled community. Even though, this community is often referred as minority community but their population is growing day by day. Therefore an appropriate and accessible public transportation service is required in all the national parks in Malaysia.
\end{abstract}

Index Terms-Disabled, national park, transportation, tourist.

\section{INTRODUCTION}

Tourism is now a global industry involving hundreds of millions of people in international as well as domestic travel each year. The World Tourism Organization estimated that there were 698 million international travelers in 2001, this amounts to approximately 10 per cent of the of the world's population. Tourism comprised of the temporary movement of people to destinations outside of their normal places of work and residence, the activities undertaken during the stay in those destinations and the facilities created to cater for their needs. Tourism is multi-dimensional and can be compartmentalized in a number of ways. There are two major variables such as origin-destination relationship and the motivation for travel. Tourism can be divided into four categories such as international tourism, internal tourism, domestic tourism and national tourism. Major reasons for tourist travel are escape, relaxation, play, strengthening family bonding, prestige, social interaction, sexual opportunity, educational opportunity, self-fulfillment and shopping. Tourists can be distinguished from excursionists (visitors) in such definition as an excursionist is someone who visits and leaves without staying a night in destination [1]. The World Tourism Organization (WTO) defines

\footnotetext{
Manuscript received July 31, 2013; revised September 29, 2013. This work was supported in part by the Ministry of Higher Education of Malaysia and Johor National Park Corporation under Vote C034. Accessible Transportation System for the Disabled Tourist in the National Park of Johor State, Johor, Malaysia.

Shalini Sanmargaraja and Seow Ta Wee are with the Faculty of Technology Management, Universiti Tun Hussein Onn Malaysia (e-mail: angelanamika86@gmail.com,seowtawee@gmail.edu.my).
}

tourists as people travelling to and staying in places outside their usual environment for not more than one consecutive year for leisure, business and other purposes [2].

Tourism is an important industry that has contributed to the growth of the economy of Malaysia. This is reflected in the tourism receipts that have increased steadily from RM 17,335.4 million in 2000 to RM 31,954.1 million in 2005. The tourist arrivals to Malaysia had also increased from 10.2 million in 2000 to 16.43 million in 2005. As such, an appropriate model and analysis for tourist arrivals is helpful to the tourism related industries and organizations in their future planning [3]. Malaysia is well endowed with abundance of natural resources particularly suitable for sustainable tourism. Tourism industry maintains its sustainability through its economic viability. Increasing attention has been given by the Malaysian government to develop sustainable tourism as an alternative source of foreign exchange to remedy the balance of payment deficit during 1980's. Tourist expenditure is not only contributing significantly to the direct tourism related sectors but also generating ripple effects on other sectors of the economy. Thus, tourism stimulates the economic progress of developing economies and its importance is gaining widespread recognition. Unlike many developing nations, tourism industry is now considered as one of the important engines of development for the Malaysian economy receiving vital focus in the government's industrial strategy [4].

Tourism is a rapidly growing industry in the Asian and Pacific region and people with disabilities and older persons are becoming a growing group of consumers of travel, sports, and other leisure-oriented products and services. People with disability have a right to and do want to enjoy travel leisure experiences. Furthermore, with regard to physical access, families with young children who are also becoming part of this increasing tourist market have similar needs to persons with disabilities and older persons. However, their travel experiences are still characterized by transportation constraints, inaccessible accommodation and tourism sites, and inadequate customer services. Thus large numbers of people require tourism to be made barrier-free. Although the number of tourists who would benefit from accessible facilities and services is on the increase, most tourism services providers in the United Nation Economic and Social Commission of Asia and the Pacific (ESCAP) region have still not yet recognized the importance of taking action on this issue. Most hotels, transportation facilities and tourist sites are not physically accessible for many people with disabilities and older persons. Their staff members have not been trained to provide disabled person-friendly services. This is associated with an absence of explicit government 
policies and strategies for promotion of accessible tourism, lack of training for tourism service personnel on means of meeting the access needs of tourists with disabilities and shortage of tourism programs that address such needs [5].

Tourists, today are not content with staying within the confines of a resort hotel compound, being bused to individual sites and entertained in places that mainly cater to tourists. Instead, tourists are increasingly interested in experiencing diversity of holiday environment in all aspects including its people, culture, nature, architecture and way of life. This trend will be even more marked as consumers become better informed about options and entitlements as well as more sophisticated and less willing to accept poor quality facilities and services that entail discomfort and stress. In view of the changing consumer demand, tourism for all is an increasingly important sales argument in a competitive market. At the same time, it can serve as an effective tool in furthering the human rights of people with disabilities in the destination communities [5].

The world's disabled population is over 500 million and represented about $8 \%$ of the population. This point is widely recognized that people with disabilities as well as their careers, friends and relatives and the elderly comprise a large segment of the consumer market potential for the tourism industry. Therefore, people with disabilities who come to visit is consider as an important market in the developing world tourism industry. Although studies on tourism and people with disabilities have increased, detailed research on disabilities rather in the tourism sector is very less. The right to travel and access travel activities should be regarded as major social rights for people with disabilities and their families. Travel and tourism is a factor in the quality of life for all people. For persons with disabilities and their families out on vacation can be a very important opportunity to relax from the stress [6].

\section{A. Disabled Tourism}

According to the World Health Organization (WHO), 35\% of people over 65 have some type of disability. Senior tourism is a segment that has not held great importance in the tourism industry, although this trend is changing. The importance of the senior citizen segment in markets in general is determined by the process of aging which is linked to improvements in the economic status and the health conditions of this group [7].

This lack of consensus highlights its fragility and its impact on two key issues, from a theoretical view, the lack of a conceptual framework to research the behavior of the elderly and from an applied perspective, the lack of suitable tools to identify the senior. This phenomenon is clearly reflected when analyzing the literature. Thus, use the term "senior" for those 55 years of age or older and non-seniors are those under 55 but over 15 years of age. In turn, these authors segment seniors into two subgroups: younger seniors from 55 to 64 years old and older seniors, 65 and older. On the other hand, some companies set the senior age break at 55 years of age, the age at which the consumer begins to sense different needs and forecast and plan for aging. From this age, they are considered as part of the segment of the elderly in the banking system, which begins to differentiate between and specialize treatment for them. Other companies set the boundary at 60 , the age that marks the differentiation between older people and the mature and begin to consider the possibilities of offerings that are appropriate to the interests and realities of this group [7].

When talking about tourism for people with disabilities, or limited or restricted capacities, one of the biggest problems is the great variety of existing words to convey very similar ideas. There is also the concept of accessible tourism for all. Almost identical to tourism for all, this concept "is not based on the separate creation of services for people with disabilities but aims at the full integration and inclusion of people with special needs, particularly disabled people and elderly people, in the tourism sector. In relation to quality tourism, it is essential to define the term quality to understand the extent to which it can be applied to tourism based on the disabled user. Quality can be defined from multiple perspectives. One of the most interesting perspectives comes from the discernment of value, defined as a property or a set of properties inherent to a product or service that permits it to be appreciated equally, better or worse than others like it. Meeting the needs and expectations of consumers of products or services is the key to quality, which should not be perceived as a luxury or privilege but as a tool to differentiate the positioning to competitors. Working with accessibility in the tourism sector results in a number of advantages that can be converted into opportunities that are reflected both in the senior segment of tourists as well as tourists who are disabled or have temporarily restricted capacities [7].

\section{B. Disability}

Disability no longer means a condition, an incapacity or lack that belongs to a body but rather a product of the interactions between self, society, body and the variety of interactions (from political economies to personal commitments) that they engender [8]. Impairment has been defined as "lacking part or all of a limb, or having a defective limb, organ or mechanism of the body". Handicap is "the disadvantage or restriction of activity caused by disability" [9]. The International Classification of Impairments, Disability and Handicap (ICIDH) use different terms such as impairment, disability and handicap. Impairment is defined as any loss or abnormality of psychological, physiological or anatomical structure or function. Disability is defined as any restriction or lack (resulting from an impairment) of ability to perform an activity in the manner or within the range considered normal for a human being. Handicap is defined as a disadvantage for a given individual, resulting from impairment or a disability that limits or prevents the fulfillment of a role that is normal (depending on age, sex, social and cultural factors) for that individual [10].

The increment in the disabled person in the population has resulted in the existence of demand for the provision of special facilities for the disable person in the forest recreation park so that they can also have the easy access to the facilities without needing help from the third party.

Disabled person consists of $0.13 \%$ of Malaysian population. There are a total of 359, 203 people who are disabled in Malaysia. Disability is dived into several categories such as visually impaired, hearing, physical, 
learning disability, speech, mental and others. Clear data is shown in Table I and Table II.

TABLE I: NuMBER OF DisABLED PERSONS REGISTERED By STATE AND TYPE OF DISABILITY, MALAYSIA 2011 [11]

\begin{tabular}{|c|c|c|c|c|}
\hline State & $\begin{array}{l}\text { Visually } \\
\text { Impaired }\end{array}$ & Hearing & Physical $^{\text {a }}$ & $\begin{array}{l}\text { Learning } \\
\text { Disability }\end{array}$ \\
\hline Malaysia & 31,924 & 43,788 & 123,346 & 134,659 \\
\hline Johor & 3,094 & 4,732 & 13,191 & 19,396 \\
\hline Kedah & 2,823 & 3,070 & 9,395 & 9,449 \\
\hline Kelantan & 3,570 & 4,612 & 10,315 & 8,720 \\
\hline Melacca & 1,126 & 2,024 & 6,270 & 7,828 \\
\hline Negeri Sembilan & 1,259 & 1,689 & 6,867 & 7,321 \\
\hline Pahang & 1,469 & 2,092 & 7,457 & 6,973 \\
\hline Perak & 2,765 & 3,779 & 12,305 & 13,567 \\
\hline Perlis & 605 & 564 & 2,041 & 2,003 \\
\hline Penang & 1,908 & 3,042 & 8,832 & 8,104 \\
\hline Sabah & 2,123 & 2,805 & 6,105 & 7,206 \\
\hline Sarawak & 1,950 & 2,459 & 5,699 & 6,883 \\
\hline Selangor & 3,709 & 6,271 & 19,059 & 19,171 \\
\hline $\begin{array}{l}\text { Terengganu } \\
\text { W.P. Kuala }\end{array}$ & 2,315 & 2,644 & 6,704 & 8,413 \\
\hline Lumpur ${ }^{\mathrm{b}}$ & 3117 & 3,918 & 8,872 & 9,193 \\
\hline W.P Labuan & 55 & 87 & 279 & 432 \\
\hline
\end{tabular}



${ }^{\mathrm{b}}$ Includes W. P. Putrajaya

TABLE II: CONT

\begin{tabular}{lrrr}
\hline State & Speech & Mental & Others \\
\hline Malaysia & $\mathbf{7 2 5}$ & $\mathbf{8 , 9 2 7}$ & $\mathbf{1 5 , 8 3 4}$ \\
Johor & 100 & 1,436 & 1,661 \\
Kedah & 66 & 623 & 1,403 \\
Kelantan & 124 & 678 & 3,592 \\
Melacca & 37 & 511 & 529 \\
Negeri Sembilan & 30 & 469 & 537 \\
Pahang & 86 & 696 & 1,049 \\
Perak & 30 & 1,018 & 1,166 \\
Perlis & 16 & 143 & 215 \\
Penang & 19 & 494 & 784 \\
Sabah & 26 & 190 & 1,481 \\
Sarawak & 69 & 542 & 434 \\
Selangor & 52 & 1,213 & 1,723 \\
Terengganu & 22 & 439 & 825 \\
W.P. Kuala Lumpur & & 462 & 420 \\
W.P Labuan & 5 & 13 & 15 \\
\hline \hline
\end{tabular}

${ }^{a}$ Includes cerebral palsy

b Includes W. P. Putrajaya

\section{TRANSPORTATION}

To address the transportation needs of people with developmental disabilities, various forms of transit have been developed. Fixed route services are common in urban communities; these can include line haul buses, trains, and subways. Flexible services, wherein a rider can schedule transportation to and from a desired location at a specific time, are found in both urban and rural communities. Other types of transportation systems include vanpools, carpools, agency vehicles, transportation for health care, and voucher programs [12].

Policies on the mobility and transport of the elderly and the disabled have developed centering on those who are the objects of welfare measures. Since the 1970s, the terms "normalization" and "barrier- free design", which are basic terms related to welfare, have been used together with the term "welfare community development" that integrates the first two terms. After 1990, when the popularization of barrier-free design started to accelerate in fields such as architecture and transport, the term "universal design" made its debut as a term for "measuring everybody", thus departing from the idea being limited to the disabled or elderly. Some prefectures and cities set up a "universal design office". The Ministry of Land, Infrastructure and Transport in Japan has implemented a project for universal design ("social inclusion") [13].

In the past, it has been difficult for the disabled to use various types of building design, roads and transport facilities. Therefore, the importance of removing such barriers was emphasized. Barrier-free design means a design that removes those barriers that obstruct the social participation of disabled people. In contrast, universal design, which is not limited to the elderly or disabled alone, as in the case of barrier- free design, aims at facility design that everyone finds easy to use. In terms of the barriers that obstruct the social participation of the disabled, there are four categories, those related to physical matters, information, systems, and consciousness [13].

What makes barrier-free design and universal design incomprehensible is simply the difference in understanding of these terms between the U.S. and Japan. In the U.S., "barrier-free design" has, in recent years, taken on a negative connotation as a term that means specifications used by only the disabled. In contrast, the term "barrier-free design" is more widely used in Japan to imply universal design. In this regard, it is natural that universal design in Japan is thought to be a concept that has evolved from barrier- free design [13].

Changes to the mainstream environment that address the access needs of one section of the disabled population may pose problems for others. Equally important is the assertion that 'different people with the same impairment may require different accommodations because everyone experiences their own impairment differently'. In terms of compatibility, whilst bright lighting may be a suitable accommodation for people with certain visual impairments, it can pose significant problems for people with epilepsy or seizure disorders. Indeed, the widespread acceptability of universally designed products and environments may prove to be an elusive ideal no matter how thoughtful designers and architects attach to their designs. To enable persons with disabilities to live independently and participate fully in all aspects of life, government shall take appropriate measures to ensure persons with disabilities access on an equal basis with others, to the physical environment, to transportation, to 
information and communications, including information and communication technologies and systems and systems and to other facilities and services open or provided to the public both in urban and rural areas [14].

The report 'Improving the life chances of disabled people' (PMSU, 2005) emphasized the need to improve the provision of transport to enable disabled people to live more independent lives. The report states that, as a result of economic disadvantage, disabled people are more likely than the general population to be reliant on public transport [15].

\section{A. Transportation Problems}

There are several problems which are outlined in literature such as delay of arrival time of public transport, lack of physical facilities, difficulty traveling by air and safety measurements.

\section{B. Delay of Arrival Time of Public Transport}

The current issues and problems regards the time arrival delaying in the Light Rail Transit (LRT) and Keretapi Tanah Melayu Berhad (KTMB) public transports when the Malaysia Prime Minister himself take the experienced by went and used that service. He was not satisfied with the service quality provided by this public transports after used the LRT service in term of punctuality and frequencies of train arrive this is because insufficient space to carry more passengers and others whereby the congestion occurred. This issue showed even the public transportation is modernized and in the urban areas but service quality is still lacking and not well implemented. This will lead to negative perception and not satisfy the consumer using the public transports. The problems also faced by the people in urban areas which in Kuala Lumpur capital of Malaysia, the bus was still late despite the route stating that the bus would arrive every 15 minutes but the user waiting until half an hour. This is punctuality problems faced by the public buses in Malaysia [16].

\section{Lack of Physical Facilities}

Generally in term of physical facilities of the public transports are insufficient, this is because the public buses mostly not provided with convenience facilities to the disabled person who are using wheelchair to board. The public buses mostly don't provide the ramps to disabled person to be more convenience to use the public transports. The scenario is different in other country like Japan, Tokyo which has their public transport system and the built environment is fully accessible. They have portable ramps in all train stations where there is a difference in height between the platform and train and stations masters are always ready to assist wheelchair users when requested [16].

People in wheelchairs have very obvious problems in moving and travelling about, especially in moving over uneven or icy surfaces and in mounting steps and kerbs. Specific, but well-defined, measures are needed to accommodate them. They only account for three or four per cent of the people who have difficulty in travelling but measures to help them help everyone, mobility-handicapped or not. A greater number of people have sensory problems (deficiencies with seeing, hearing or speaking) which make it difficult or impossible for them to find their way, select an appropriate public transport service, buy a ticket, alight at their chosen destination or communicate with other people (including transport staff) on the way; people with intellectual impairments share many of the same problems. Better provision of information to help this group will also help able-bodied people. Arthritis, loss of limbs or impaired motor functions produce specific physical problems with one or more aspects of travelling: for example, climbing a kerb, boarding a vehicle, walking to a stop or station and standing waiting for the service to arrive. Again, measures to help this group will also help all other travelers, especially those with luggage or children, and frail elderly people [17], [20].

\section{Difficulty Traveling by Air}

For people with disabilities a foundation of any tourism experience is having accessible destinations and locating appropriate accommodation from which to base one while traveling. Once this is determined in the travel-planning phase, people need to travel to the destination region. A greater proportion of people around the world now use air travel as their preferred mode of travel as it has been democratized through the advent of low-cost airlines. Studies in Australia have shown that air travel creates a series of constraints for people with disabilities. The doors of aircrafts are too small and can't be accessed by the wheelchairs. A densely packed low-cost airline also problems with respect to the particular seats allocatted, the presence of restrictive armrests, and the lack of leg space affecting people with conditions like rheumatoid arthritis. There are even more serious concerns with respect to going to the toilet and the lack of wheelchair accessible toilets and onboard aisle chairs. People with disabilities try to prepare for the worst and use ground toilet facilities; many can cope with this alternative for a short-haul flight, but as Low Cost-Carrier (LCC) contemplate extending their business model to long-haul flights, this warrants some consideration [18].

\section{E. Safety Measurements}

The second incident occur one month after the first issues that stated above, in 25 September 2008 at urban area which is Kuala Lumpur when two LRT train Rapid KL clashing each other in 200 meter from Bukit Jalil station. This incident also showed the problems of the service quality in term of safety measurement of the public transports become worse and in the critical case. Therefore the quality in term of service must be concerned extremely because to make sure the peoples or user satisfied and give positive perceptions towards the public transports provided as well as in urban or rural areas. In the face of such a fierce scenario, the public transport sector cannot limit itself to maintaining its current level of performance. Due to this incident many seniors are afraid to travel by trains [16].

\section{F. Too Costly}

No discounts are given to the disabled people on the public transport such as bus and trains. People with mobility handicaps are generally poorer than those without. They are less able to work (not least because of the problems of travelling to work) and they earn less on average when they do. Thus they have to rely on cheaper forms of transport and they may travel less often; specifically, those who could drive 
often cannot afford to own or run a car, which might otherwise go a long way to solving their mobility problem [17].

\section{Methodology}

\section{A. Study Area}

The study has been conducted at the national park in Johor, especially in Pulau Kukup, Tanjung Piai, Gunung Ledang and Endau-Rompin. The research design consisted of a observation and interview. The focus of this study is on transportation facilities inside and outside the national park and the data were compared between the study locations. Many researches is being conducted in this area due to the development of the Iskandar Development Region (IDR) and South Johor Economic Region (SJER). Tourism market in the study area is increasing from year to year and this is contributing to the economy. Accurate data is shown clearly in Table III.

TABLE III: NUMBER OF MALAYSIAN TOURISTS TO JOHOR NATIONAL PARK FROM 2010 TO 2012

\begin{tabular}{lccrr}
\hline \hline National Park & 2010 & 2011 & 2012 & Total \\
\hline Endau Rompin & 3,515 & 2,396 & 2,453 & 8,364 \\
Pulau Kukup & 16,137 & 33,222 & 33,688 & 83,047 \\
Tanjung Piai & 47,470 & 56,847 & 65,973 & 170,290 \\
$\begin{array}{l}\text { Gunung } \\
\text { Ledang }\end{array}$ & 10,838 & 17,837 & 26,431 & 55,106 \\
Total & 79,970 & 112,313 & 130,557 & 316,807 \\
\hline \hline
\end{tabular}

The number of tourist declined starting from 2011 due to the national park is closed for renovation. International tourists also looking for the accessible facilities so that even disabled tourist can feel the excitement in the park. Clear data is shown in TABLE IV.

TABLE IV: NUMBER OF INTERNATIONAL TOURISTS TO JOHOR NATIONAL PARK FROM 2010 TO 2012

\begin{tabular}{lrrrr}
\multicolumn{5}{c}{ PARK FROM 2010 TO 2012 } \\
\hline \hline National Park & 2010 & 2011 & 2012 & Total \\
\hline Endau Rompin & 968 & 768 & 764 & 2,500 \\
Pulau Kukup & 2,316 & 2,999 & 1,867 & 7,182 \\
$\begin{array}{l}\text { Tanjung Piai } \\
\begin{array}{l}\text { Gunung } \\
\text { Ledang }\end{array}\end{array}$ & 8,342 & 5,334 & 6,959 & 20,635 \\
Total & 4,038 & 2,178 & 1,738 & 7,954 \\
\hline \hline
\end{tabular}

\section{B. Method}

The research design consisted of observation and interview. The focus of this study is on transportation facilities inside and outside the national park and the data were compared between the study locations. The respondents consist of four staffs, one from each study location. Several questions were asked to obtain initial data in all the locations. A set of questions were prepared based on Guide for Practitioners [19]. Observation also done to obtain clear picture of actual situation.

\section{RESULTS}

\section{A. Means to Arrive at National Parks}

There are several means to arrive to national parks car or taxi, boat and jeep. There are no public buses provided in all the national parks. The only mean of transport to enter Pulau Kukup is by boat. There two ways we can enter Endau Rompin National Park which is by car or taxi and jeep but it is advisable to use jeep. The street along Endau Rompin is made of red soil, so the vehicle will be exposed to the thick dust and muddy roads due to rain. Clear data is shown in Table V.

\section{B. Perception of the Staff Regarding the Facilities in the National Park}

There are no public participation elements in all the national parks due to very limited number of disabled visitors every year. According to the staff, there are no disabled tourists at times and there will be one or two of them. Disabled tourism is still in infant stage in Malaysia due to lack of awareness in the society. Due to this situation, there is no active outreach is been conducted to identify and communicate with the organizations of older persons and persons with disabilities. No focus groups of disabled persons have been utilized and there no advisory committee of disabled persons and seniors. Discounts will be given to the disabled tourists if any. Since there is no bus service in all the national park, there is only platform for the tourists who are using boat to access Pulau Kukup. Other facilities are shown in Table VI.

\section{Location Recommendation Based on Disability Types}

Even though Tanjung Piai has inadequate facilities provided but it is accessible for the basic facilities. Therefore Tanjung Piai is recommended for all categories of disability. Gunung Ledang is not accessible for the disabled persons because this national park is meant for extreme sports activities like hiking, mount climbing, jungle trekking, high rope, camping, obstacle course and others. The speed boat in Pulau Kukup is not recommended to the pregnant ladies and senior citizens due to insecurity. Route to Endau Rompin is unpleasant and is not recommended for the pregnant ladies and senior citizens as shown in Table VII.

\section{DISCUSSION}

Basically all the National Parks in Johor State don't have accessible transportation service. There are many aspects should be attention and a lot of improvements are to make so that all the national park in research area will be disabled friendly locations. Due to lack of facilities, most people with disabilities are not really interested in visiting national parks in Johor. National Parks Corporation also not keen about making publicity in print and mass media causes people to not know much about a place of recreation provided by this corporation. Understanding the wider issues of tourist accessibility is paramount to positive tourist experiences. 
However, the challenges associated with ensuring that disabled person can freely move within and between urban environments must be fully understood before access can be sufficiently planned and managed. Tourist accessibility comprises all the tourism markets including aged person and people with disabilities who have been classified as specific groups. There are important structural barriers among all the barriers outlined that may constrain the experiences of this group in urban centers. When the public is not exposed to the existence of a national park, they will not know about its existence and Johor National Parks would not have been on the list of tourist favorite destinations. With this in mind, it is necessary to evaluate access and overcome the barriers to create 'Tourism for All' concept.

TABLE V: MEANS TO ARRIVE AT NATIONAL PARK

\begin{tabular}{|c|c|c|c|c|}
\hline National Park & Bus & Car/Taxi & Boat & Jeep \\
\hline Endau Rompin & & $\sqrt{ }$ & & $\sqrt{ }$ \\
\hline Pulau Kukup & & & $\sqrt{ }$ & \\
\hline Tanjung Piai & & $\sqrt{ }$ & & $\sqrt{ }$ \\
\hline Gunung Ledang & & $\sqrt{ }$ & & $\sqrt{ }$ \\
\hline
\end{tabular}

TABLE VI: PERCEPTION OF THE STAFF REGARDING THE FACILITIES IN THE NATIONAL PARK

\begin{tabular}{|c|c|c|c|c|}
\hline $\begin{array}{c}\text { Public } \\
\text { Participation }\end{array}$ & $\begin{array}{l}\text { Endau } \\
\text { Rompin }\end{array}$ & $\begin{array}{l}\text { Pulau } \\
\text { Kukup }\end{array}$ & $\begin{array}{l}\text { Tanjung } \\
\text { Piai }\end{array}$ & $\begin{array}{l}\text { Gunung } \\
\text { Ledang }\end{array}$ \\
\hline $\begin{array}{l}\text { Active outreach to } \\
\text { identify and } \\
\text { communicate with } \\
\text { organizations of } \\
\text { disabled persons }\end{array}$ & & & & \\
\hline $\begin{array}{l}\text { Focus groups been } \\
\text { utilized } \\
\text { Advisory } \\
\text { committee }\end{array}$ & & & & \\
\hline Fare Collection & & & & \\
\hline $\begin{array}{l}\text { Advantage of a flat } \\
\text { rate for disabled } \\
\text { persons }\end{array}$ & $\sqrt{ }$ & $\sqrt{ }$ & $\sqrt{ }$ & $\sqrt{ }$ \\
\hline $\begin{array}{l}\text { Platform to Bus } \\
\text { Floor Gap }\end{array}$ & & & & \\
\hline $\begin{array}{l}\text { Station door } \\
\text { prioritized for } \\
\text { disabled users }\end{array}$ & $\sqrt{ }$ & & $\sqrt{ }$ & $\sqrt{ }$ \\
\hline $\begin{array}{l}\text { Station assistants } \\
\text { trained to assist } \\
\text { disabled persons }\end{array}$ & & & & \\
\hline $\begin{array}{l}\text { Gap eliminated for } \\
\text { all passengers by } \\
\text { boarding bridges } \\
\text { lowered from all } \\
\text { bus }\end{array}$ & & & & \\
\hline $\begin{array}{l}\text { Access at Feeder } \\
\text { Line Stops }\end{array}$ & & & & \\
\hline $\begin{array}{l}\text { Accessibility } \\
\text { features phased in, } \\
\text { prioritizing } \\
\text { high-use bus stops }\end{array}$ & & & & \\
\hline \multirow{2}{*}{$\begin{array}{l}\text { Enforcement } \\
\text { planned to keep } \\
\text { bus stops free of } \\
\text { other vehicles }\end{array}$} & & & & \\
\hline & $\sqrt{ }$ & & $\sqrt{ }$ & $\sqrt{ }$ \\
\hline
\end{tabular}

waiting areas meet

accessibility

criteria

Other Supporting

Facilities

Ramp

Handrail

Access Route

Roof Walkways

Self-Service

Equipment

Reserved Seating

Areas

Access to

Information

Self-Service

Wheelchair

Equipment

TABLE VII: LOCATION RECOMMENDATION BASED ON DISABILITY TYPES

\begin{tabular}{lcccc}
\hline \hline National & & Mental & Temporary & $\begin{array}{r}\text { Pregnancy/ } \\
\text { Park }\end{array}$ \\
\hline Endau & Impairment & Illness & Injury & Senior citizen \\
Rompin & $\sqrt{ }$ & $\sqrt{ }$ & $\sqrt{ }$ & \\
Pulau & & $\sqrt{ }$ & $\sqrt{ }$ & \\
Kukup & & $\sqrt{ }$ & $\sqrt{ }$ & $\sqrt{ }$ \\
Tanjung Piai & $\sqrt{ }$ & & & \\
Gunung & & $\sqrt{ }$ & \\
Ledang & $\sqrt{ }$ & $\sqrt{ }$ & \\
\hline \hline
\end{tabular}

\section{CONCLUSION}

From observations and interview session, it is found that all of the Johor National Park does not have adequate facilities for the disabled. Due to lack of facilities and constraints in transportation service, most people with disabilities are not really interested in visiting national parks in Johor.

Provision of accessible facilities is far more important in doubt to achieve barrier-free tourism for people with disabilities. Assumption of things will change overnight is highly unrealistic due to the limitations of cost and short time. Things which are needed in the short term are a reasonable level of accessibility can balance the needs of users with disabilities, the constraints of the existing situation and the resources available for adjustments. In many cases, this is related to the physical adjustment and financial support. In the long run, provide more in-depth approach to promoting the restructuring and overhaul of the hospitality and tourism sector.

Education and training on awareness and sensitivity to disability issues should be more in promoting tourism accessibility. Close collaboration between disabled organizations and tourism industry along with the education sector will facilitate the development of training programs required. It will also help in the production of such guidelines facilitative training and support audio-visual training in the 
tourism industry. Many seminars which highlight the obstacles of disabled, the challenges faced by the disabled and solutions to all the issues that arise should be widely held more frequently to show our appreciation towards this group of people. Accessibility and tourism integration is included in the Corporate Social Responsibility strategy and business development, this will be a challenge in the future to contribute to the development of tourism standards.

\section{ACKNOWLEDGMENT}

My sincere appreciation and thanks to the Faculty of Business and Technology Management and Centre of Graduates Studies of Universiti Tun Hussein Onn Malaysia (UTHM) for the support, guidance and assistance given. Thank you.

\section{REFERENCES}

[1] P. Mason, Tourism Impacts, Planning and Management, England: Elsevier Butterworth-Henemann, 2006, pp. 1-5.

[2] S. Patil. (May/June 2012). Sustainable tourism development in Konkan: A need of time. Electronic International Interdisipinary Research Journal (EIIRJ). [Online]. 1(3). pp. 111-125. Available: http://eiirj1.weebly.com/uploads/1/0/8/0/10800505/10sp.pdf

[3] C. R. Goeldner and J. R. B. Ritchie, Tourism: Principles, Practices, Philosophies, 10th ed. United States of America: John Wiley \& Sons, Inc. 11, 2006, pp. 1-50.

[4] M. Shitan, C. K. I. M. Yew, and M. K. Gounder, "Detecting outliers for tourist arrivals to Malaysia using REGARIMA Model," in Proc. the 2nd IMT-GT Regional Conference on Mathematics, Statistics and Applicant, Malaysia, 2006, pp. 1-7.

[5] United Nation Economics Social Commission of Asia and the Pacific (ESCAP), "Barrier-Free Tourism for people with disabilities in the ESCAP Region," in Proc. the Asia-Pacific Conference on Tourism for People with Disability, Indonesia, September 24-28, 2000, pp. 69-89.

[6] S. Sanmargaraja and S. T. Wee, "Preliminary study on the preparation of facilities for the disabled in the National Parks in Johor State: A case study in Pulau Kukup, Tanjung Piai, Gunung Ledang and Forest Park of Endau-Rompin," presented at the International Conference on Social Science and Management, Indonesia, August 5-8, 2013.

[7] E. Alén, T. Domínguez, and N. Losada, Visions for Global Tourism Industry-Creating and Sustaining Competitive Strategies, University of Vigo, Spain, 2002, pp. 140-166.

[8] A. M. Institute of Medicine (U.S.), Committee on Disability in America Field and Marilyn J. Jette, Definition and Monitoring of Disability, Washington, D.C., 2007, pp. 35-64.

[9] V. Finkelstein, Attitudes and Disabled People: Issues for discussion, 2012, pp. 1-63.

[10] C. Barnes. (2011). Understanding disability and the importance of design for all. Journal of Accessibility and design for All. [Online]. 1(1), pp. $55-80$ Available: http://www.jacces.org/jacces/ojs/index.php/jacces/article/download/5 $6 / 15$

[11] Ministry of Department of Statistics, Social Statistics Bulletin, 2011, pp. $1-198$.

[12] C. Giertz, Freedom to Ride, 2013, pp. 1-13.

[13] T. Akiyama, "Japan's transportation policies for the elderly and disabled," in Proc. European Conference of Ministers of Transport, March 2005, pp. 1-13.

[14] C. M. Hall, "Tourism and mobility," presented at the CAUTHE Conference, Brisbane, Queensland, 2004, pp. 1-9.

[15] O. GfK NOP Social Research, "Experiences and expectations of disabled people," 2008, pp. 1-244.
[16] Z. Zakaria, Z. H. Hussin, M. F. A. Batau, and Z. Zakaria. (2010). Service Quality of Malaysian Public Transports: A Case Study in Malaysia. Journal of Cross-Cultural Communication. [Online]. 6(2), pp. 84-92. Available: http://www.questia.com/library/1P3-2087472021/service-quality-of-m alaysian-public-transports-a

[17] European Conference of Ministers of Transport (ECMT). (1991). Transport for people with mobility handicaps: Policy and achievements in Europe. [Online]. pp. 1-19. Available: http://www.internationaltransportforum.org/IntOrg/ecmt/accessibility/ pdf/tphpolicye.pdf

[18] S. Darcy and R. Ravinder, “'Last out of the plane': Air travel for people with disabilities," presented at the Conference on Tourism in India, May, 15-17, 2007.

[19] T. Rickert, "Technical and operational challenges to inclusive Bus Rapid Transit: A guide for practitioners," 2010, pp. 1-42.

[20] S. Shalini and S. T. Wee. (May 2012). Preparation of Facilities Needed and Perception of Occupants in The Old Folk's Home: Case Study in Ipoh and Johor Bahru. OIDA International Journal of Sustainable Development. [Online]. 4(3). pp. 29-42. Available: http://papers.ssrn.com/sol3/papers.cfm?abstract_id=2054136

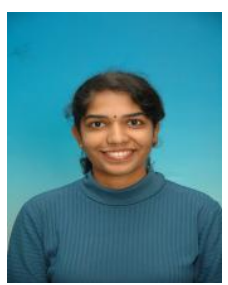

Shalini Sanmargaraja was born in Taiping, Malaysia on April 23, 1986. She holds a master degree in MSc Real Estate and Facility Management from Unversiti Tun Hussein Onn Malaysia (UTHM), in year 2012 She holds a bachelor degree in BSc Construction Management from Universiti Tun Hussein Onn Malaysia (UTHM). Previously, she was working as Quantity Surveyor for a year and now she is working as Research Assistant as well as pursuing her Pho studies. She has published journal entitled Preparation of Facilities Needed and Perception of Occupants in The Old Folk's Home: Case Study in Ipoh and Johor Bahru" in OIDA International Journal of Sustainable Development. At present, she is conducting on research facility management in the Nationals Parks in Johor State. She has also conducted studies such as facility management on persons with disabilities (PWDs) in government institutions and facilities management in the elderly home.



Seow Ta Wee was born in Semerah, Malaysia on January 11, 1972. He holds a Ph.D. in Waste Management from Universiti Kebangsaan Malaysia (UKM) in year 2009. He holds a master's degree in MSc Environmental Mangement and a bachelor degree in BSc Geography from Universiti Kebangsaan Malaysia (UKM). Currently, he served as senior lecturer in Universiti Tun Hussein Onn Malaysia (UTHM). Many of his research related to socio-economic aspects in the management of solid waste such as garbage collection issues, community participation in solid waste management, recycling programs, public health issues and workers in the solid waste management facilities, public knowledge of the issue of solid waste management, policy and legislation related to solid waste, construction waste and the development of indicators of sustainable solid waste management. Dr. Seow Ta Wee has produced more than 120 seminars articles, books and chapters in books on national and international levels on solid waste management and environmental issues. $\mathrm{He}$ is also a consultant in policy-making at the national level, especially in parts of the local government recycling program planning and review policies formed and become facilitators in recycling programs. He is also an active member talks about recycling and solid waste in schools. Apart from research on solid waste management, he also conducted research on facilities with the people with disabilities (PWDs), environmental impact assessment (EIA), safety and health, environmental management systems (ISO 14000 series), maintenance of buildings and Polycylic Aromatic Hydrocarbons (PAHs). 